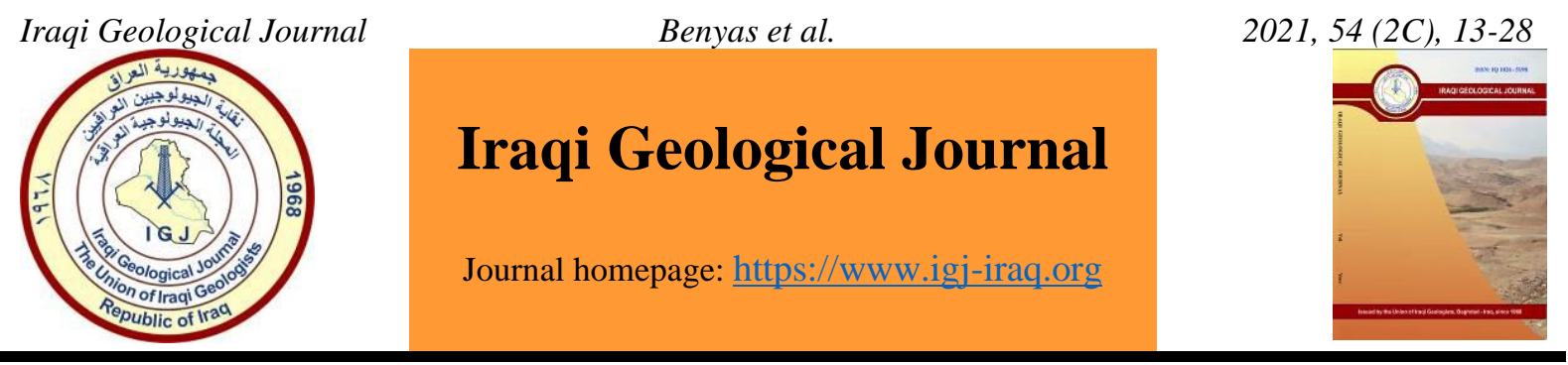

\title{
Exploiting Aeromagnetic and Gravity Data Interpretation to Delineate Massif Deposits of Rehamna Area (Western Meseta-Morocco)
}

\author{
Kawtar Benyas ${ }^{1}$, , Abdellatif Aarab ${ }^{1}$, Abdelmounim Qarbous ${ }^{2}$, Abdellah Lakhloufi ${ }^{1}$, Ahmed \\ Manar $^{3}$, Mounir Amar ${ }^{4}$, Assia Idrissi ${ }^{5}$ and Mohamed Elmimouni ${ }^{1}$ \\ Laboratory of Analysis and Modelling of Water and Natural Resources. Mohamed V University - Rabat. Morocco \\ Scientific Institute. Department of Earth Sciences, Rabat, Morocco \\ Ministry of Energy, Mines, and Sustainable Development, Geology Directorate, Applied Geology Division. Morocco \\ Cherifien Phosphates Office \\ Department of Earth Sciences, Faculty of Sciences. Mohamed V University, Rabat, Morocco \\ * Correspondence: benyas.kawtar@gmail.com
}

Received: 5 May 2021; Accepted: 25 July 2021; Published: 30 September 2021

\begin{abstract}
The analysis of the magnetic signatures and gravity gradient values of the Rehamna Massif south of the Moroccan Western Meseta by using Geosoft Oasis Montaj 7.0.1 software, allowed us to detect several useful anomalies to be exploited and which are related to magmatic bodies and structural features within the study area. These data were analyzed by applying several techniques, including the horizontal gradient filters combined with the first vertical derivative. Subsurface structures; such as geological boundaries, faults, dykes and folds, were visualized as lineaments on geophysical maps, then results were compared with structural features provided by previous studies in the region. Thus, the Rehamna Massif structural map shows sets of linear features which may represent faults or boundaries of geological structures, which can be either faults or boundaries of geological structures, and they are mostly oriented in the directions: N-S, NNE-SSW, NE-SW, E-W with the predominance of the NNE-SSW to NE-SW directions. In addition, the super position of the minerals bearing beds or formations were distinguished from gravity and magnetic data processing results. Some of the recognized anomalies are related to the existence of precious metals which belong to the granitic bodies within the study area.
\end{abstract}

Keywords: Aeromagnetic analysis; Gravimetry; Horizontal gradient; Vertical derivative; Rehamna Massif; Morocco

\section{Introduction}

In Morocco, the Western Meseta is part of the Hercynian belt, known by an intense polyphase tectonic deformation (El Kamel, 1987; El Mahi et al., 1999 and 2000) and accompanied by metamorphism that is generally localized in the central part of the Rehamna Massif where it reaches the mesozonal level (Aghzer, 1994; El Mahi et al., 1999 and 2000; Hoepffner et al., 2017). At this Massif (Fig. 1), Hercynian formations overlain the Neoproterozoic basement with an angular unconformity (Hoepffner et al., 2006) and generally are surmounted by marly-limestone and phosphate series of Cretaceous age with some basaltic intercalations (Baudin et al., 2003; Gigout, 1951). Acidic magmatic

DOI: 10.46717 /igj.54.2C.2Ms-2021-09-21 
rocks outcrop in a large Hercynian granitic body (El Kamel et al., 1998). As the most of Western Meseta massifs, where known mineralization (gold, silver, copper, iron oxide, sulphur, zinc, lead) are economically exploitable (Diot, 1989; Nerci, 2006; Belkabir et al., 2008; Benhamou \& Moumou, 2015; Nshimiyimana et al., 2018). The Jbilet Massif, is located directly to the south of the Rehamna, and characterized by copper-auriferous and argentiferous vein deposits (El Arbaoui et al., 2015; Benchekroun \& Essarraj, 2015), which are trending toward NW-SE, N-S, and NE-SW (Yahyaoui \& Essaifi, 2011; Nshimiyimana et al., 2018). In the Rehamna Massif (the current study area) structural and magmatic evidences suggests the presence of magnetically susceptible and economically exploitable deposits. Currently, aeromagnetic and gravimetric surveying data analyses are used worldwide for regional geological reconnaissance and metallogenic and mining research (Abderbi \& Khattach, 2011; Bouya et al., 2013). In Morocco, aeromagnetic and gravity surveying data, unfortunately, were limited to interpretations and punctual analyses (El Gout et al., 2009, 2010; Abderbi \& Khattach, 2011; Amar et al., 2012, 2015; Bouya et al., 2013; Boutirame et al., 2019; Nait Bba et al., 2019).

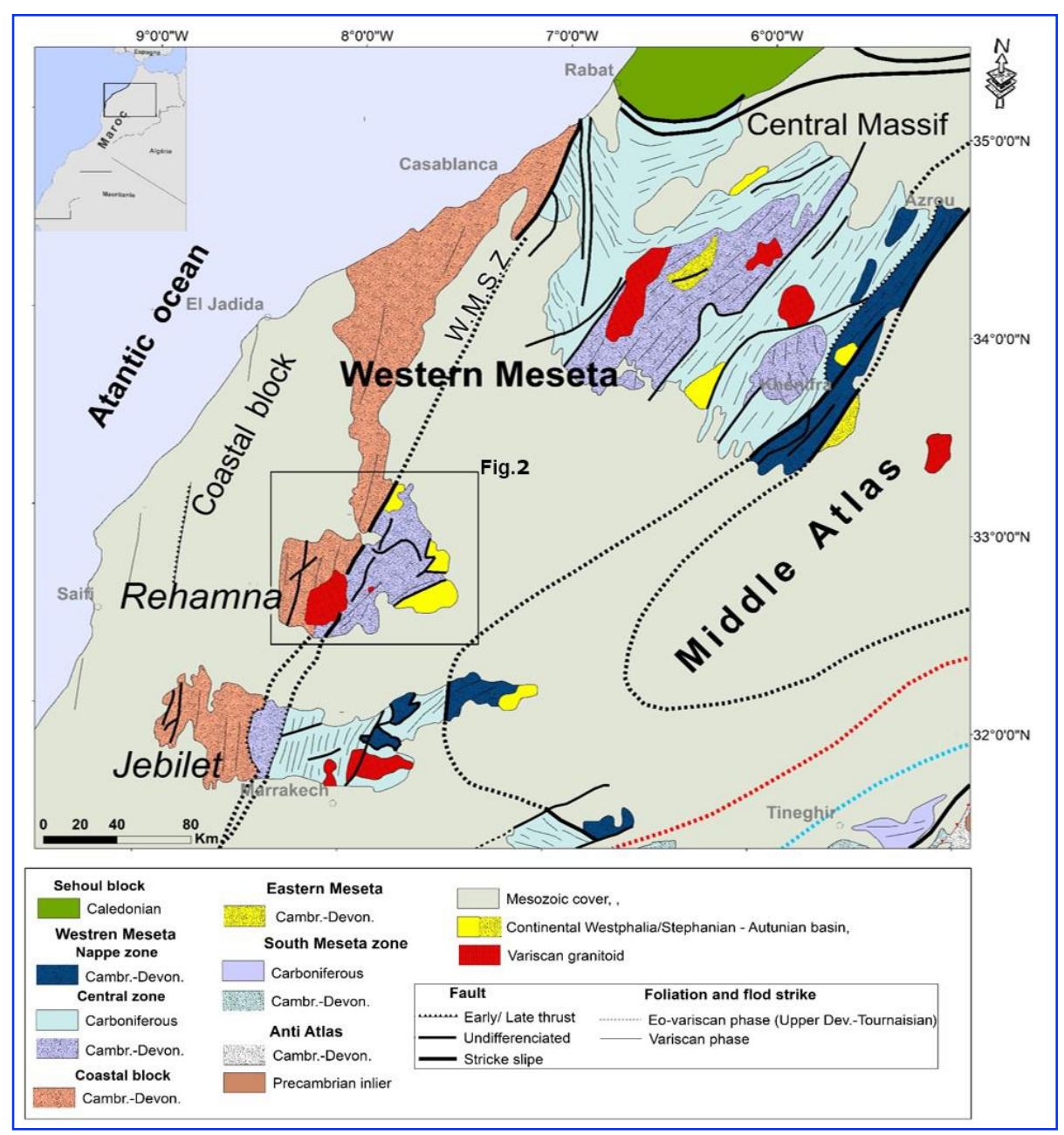

Fig. 1. Simplified geological map of Moroccan Hercynian zones (modified after Chopin et al., 2014; Hoepffner et al., 2005; Michard et al., 2010; Michard et al., 2008). Western Meseta Shear Zone (WMSZ)

The present work, therefore, consists of a geophysical study of the Rehamna Massif, through the analysis of airborne magnetic and gravity data and surveys coupled with field observations of zones with potentially exploitable mineralization showings. These methods are widely used in the field of mineral prospecting by locating anomaly zones which have vital importance in the economic 
exploitation of detecting metalliferous concentrations (Jarni et al., 2015). Furthermore, such interpretations could be helpful in highlighting the relationship between mineralization and the magmatic bodies and tectonic structures that are well developed in this area of the Meseta.

\subsection{Geological Setting}

The Rehamna Massif consists of a Precambrian basement (Fig. 2), formed of felsic volcaniclastic rocks (Piqué, 1972; Hoepffner, 1974; El Kamel, 1987; El Mahi, 1991; Hoepffner et al., 2005a), surmounted by silico-clastic and carbonate formations ranging from Lower Cambrian to Visean (Hoepffner et al., 2017; Pereira et al., 2015) intensely deformed and moderately metamorphosed (El Kamel, 1987; El Mahi, 1991). Apart from the massifs, the Hercynian formations are surmounted by a Meso-cenozoic tabular series. The Rehamna Hercynian Massif has three major Hercynian structural units: The Western, Central and Eastern Rehamna, which are separated by two major fault zones of NNE-SSW direction (Figs. 3 and 4). Towards the west, the major fault zone corresponds to the Western Meseta Shear Zone, represented here by the Median Fault, and the Tarfa Fault, which represents its continuity towards the north (Aghzer, 1994; Aghzer \& Arenas, 1998; El Mahi et al., 1999). The major fault zone to the east is represented by the Ouled Zeness Fault, the Leffaid Fault and the Foum el Mejez Fault (Aghzer, 1994; Aghzer \& Arenas, 1998; Baudin et al., 2003).

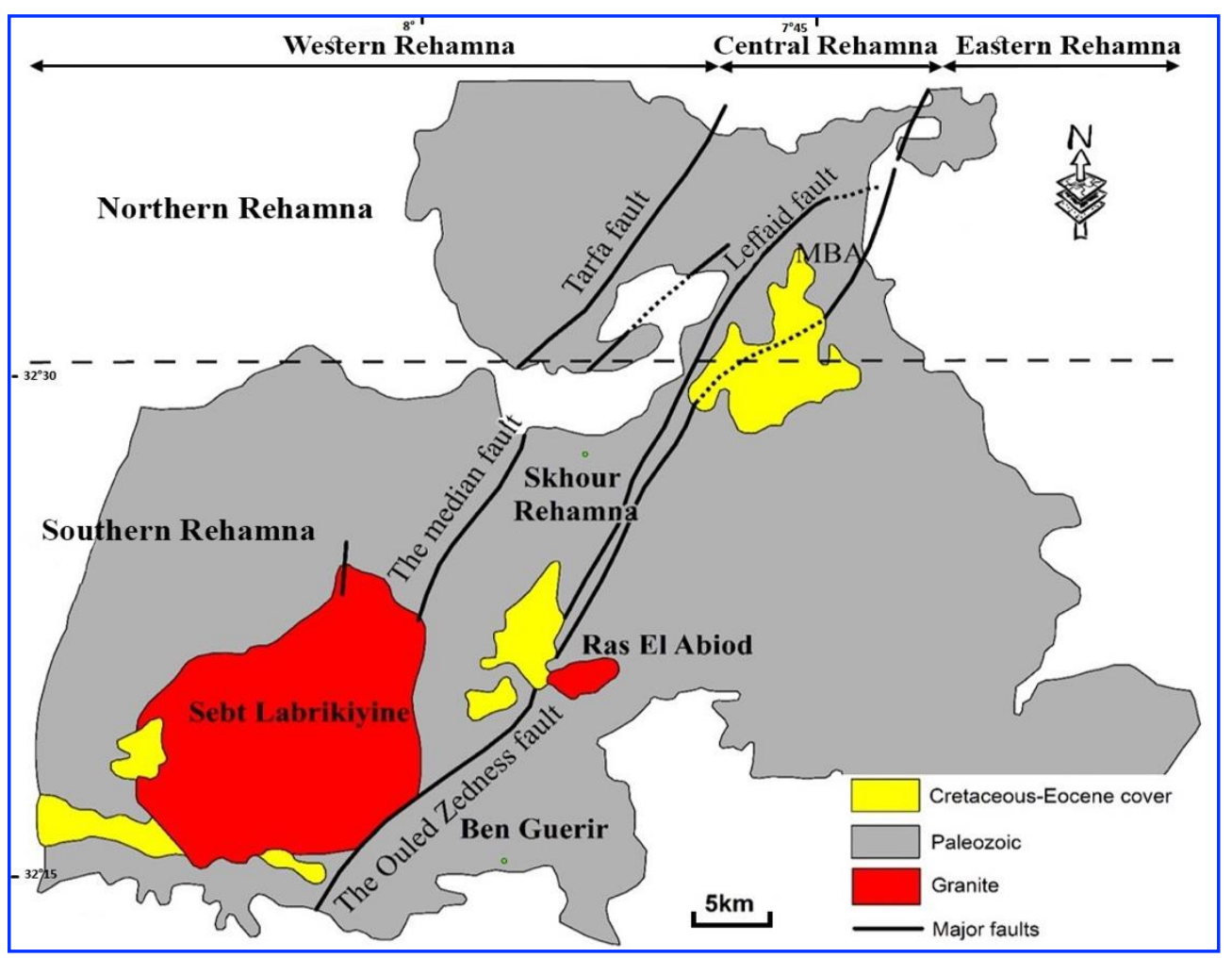

Fig. 2. A geological map showing the basement rocks of northern and southern Rehamna area. MBA: Mechraa Ben Abbou (Kholaiq et al., 2015)

In the Rehamna zone, three tectono-metamorphic phases $\left(\mathrm{D}_{1}, \mathrm{D}_{2}\right.$ and $\left.\mathrm{D}_{3}\right)$ occurred from the Upper Carboniferous to the Lower Permian (Cornee, 1982; El Mahi et al., 1999; Chopin et al., 2014; Wernert et al., 2016). Phase $D_{1}$ was responsible for the metamorphic foliation $\left(S_{1}\right)$ and the SSE overlap, which was taken up by phase $\mathrm{D}_{2}$, which is at the origin of the folds $\left(\mathrm{P}_{2}\right)$ of WNW-ESE direction, resulting from a NNE-SSW shortening (Cornee, 1982; El Mahi et al., 1999; Chopin et al., 2014; Wernert et al., 2016). This shortening is responsible for a subvertical schistosity $\left(S_{2}\right)$, taken up by a third tectonic phase 
$\mathrm{D}_{3}$, materialized by synschist folds $\mathrm{P}_{3}$, of NNE - SSW direction; the schistosity $\mathrm{S}_{3}$ is tilted towards the ESE (Chopin et al., 2014; Wernert et al., 2016).

Fig. 3. A geological and structural map of the study area showing the main rock formations and the

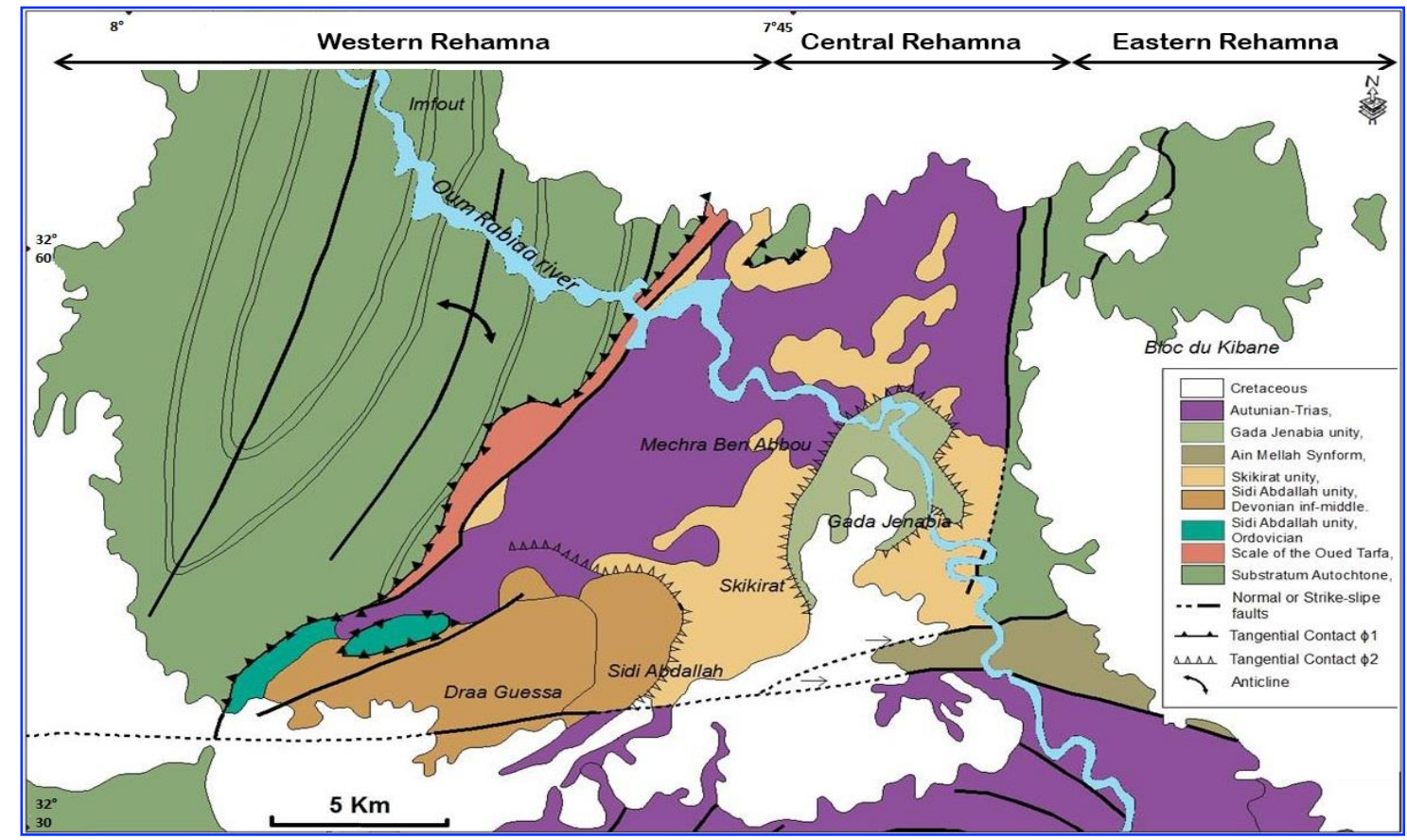

prevalent structural features (Rais-Assa, 1984)

Magmatically, the Rehamna Massif is characterized by the emplacement of numerous granitic and granodioritic plutons of Visean-Autunian age (330 to 300-290 Ma) in relationship with the distension contemporary to the sedimentation of the Upper Visean (Michard et al., 2010). These felsic magmas crop out as a diapiric ellipsoid (Baudin et al., 2003; Tahiri et al., 2007; Michard et al., 2010) or as laccolites (Boummane \& Olivier, 2007; Michard et al., 2010). They are the result of a mixture of mafic magmas from the upper mantle enriched in major chemical elements $\left(\mathrm{MgO} ; \mathrm{Al}_{2} \mathrm{O}_{3} ; \mathrm{CaO} ; \mathrm{Na}_{2} \mathrm{O}\right.$ and $\left.\mathrm{K}_{2} \mathrm{O}\right)$ and anatectic magmas derived from the partial fusion of a continental crust (Gasquet et al., 1996; Haïmeur \& Hassani, 2005; El Hadi et al., 2006; Michard et al., 2010). In the Carboniferous basins of the Rehamna Massif, felsic intrusions are generally posterior to mafic magmatism, although some magmatic breccias locally suggest the emplacement of dolerites and gabbros in the form of Late Visean sills (Essaifi et al., 2003; Michard et al., 2010).

\section{Materials and Methods}

The data used in this study are from airborne magnetic surveys acquired by the airborne magnetism campaign (African Geophysical Company, 1970). which was entrusted by the Ministry of Energy and Mines of Morocco. These surveys were recorded at a barometric flight altitude of $1000 \mathrm{~m}$. Thus, the Rehamna Hercynian Massif was covered with 53 aircraft flight lines, equipped with a magnetometer (type CSF $\mathrm{n}^{\circ} 21$ Caesium steam CSF with 6 embedded beams). The spacing between the flight lines is $3 \mathrm{~km}, \mathrm{SE} 120^{\circ}$ direction. 21 orthogonal transverse lines with a spacing of $8 \mathrm{~km}$ and NE $30^{\circ}$ orientation, perpendicular to the dominant geological trend in the region. After applying the preliminary corrections of the measurements, the acquired data were analyzed and displayed in the maps of iso grammatical lines of the residual magnetic field at a scale of 1/100 000. As for the gravimetric data, they were 
acquired from the International Gravimetric Bureau and are provided as digital files showing the Bouguer anomalies of the zone with a correction density of $2.5 \mathrm{~g} / \mathrm{m}^{3}$.

Fig. 4. Geological setting for the exposed to surface formations of the Rehamna massif (modified

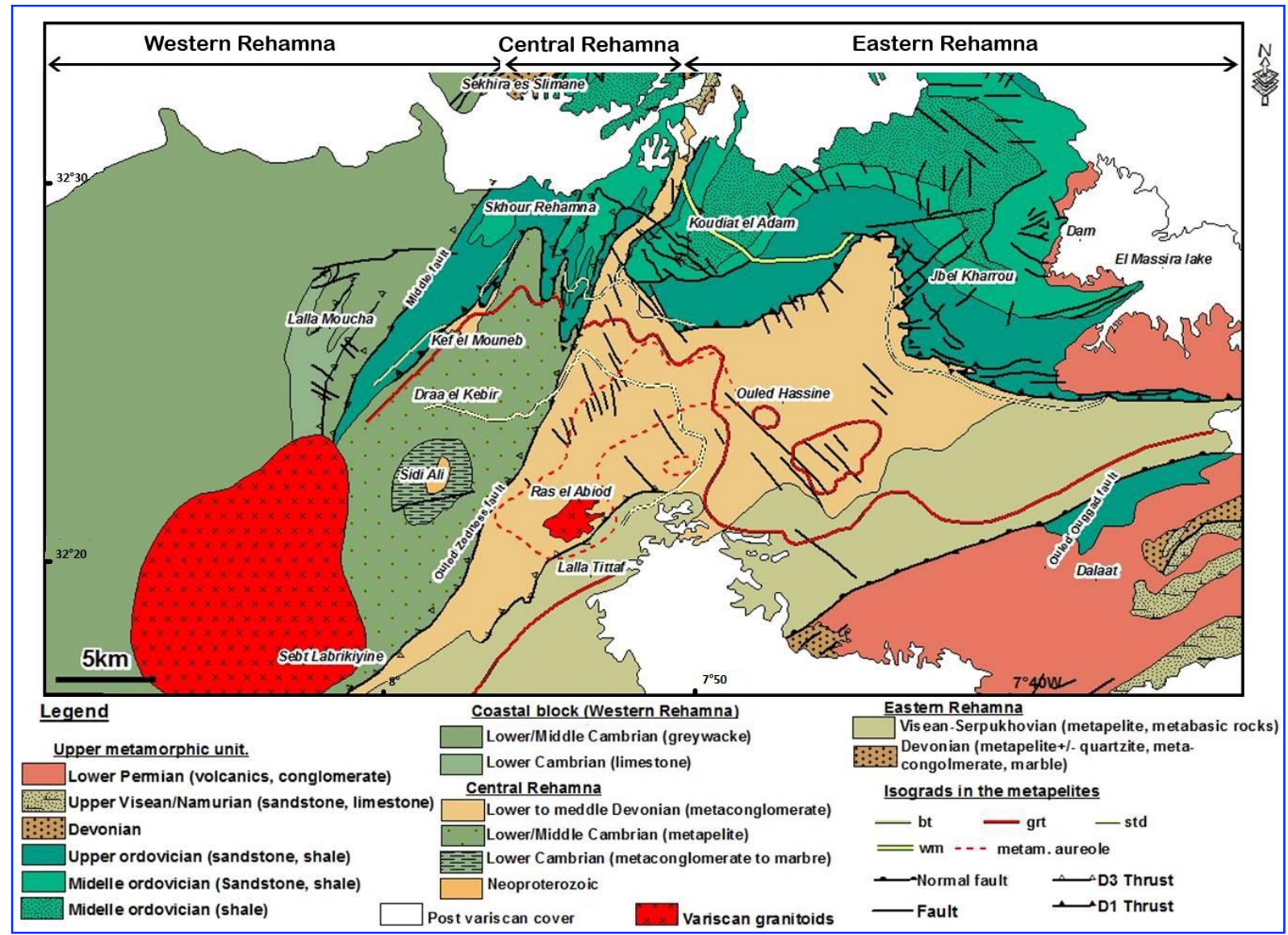

from Baudin et al., 2003; Cornée, 1982; Corsini et al., 1988; El Kamel \& El Hassani, 2006; Hoepffner et al., 1975; Michard, 1982; Michard et al., 2010; Razin et al., 2003).

Digital processing of the magnetic maps of the study area by ARCGIS 10.1 and Oasis Montaj 7.0.1 software resulted in the elaboration of a residual magnetic field map (Fig. 5a), which was reduced to the pole (Fig. 5b) by the Fourier Transform with an Inclination of 47 and a Declination of -7.4. Based on the numerical analysis of the gravimetric data, we have elaborated the Bouguer anomaly map (Fig. 6a) which reflects the excess or deficit of masses with respect to the Earth's mean distinct density $\left(2670 \mathrm{~kg} / \mathrm{m}^{3}\right)$. The Bouguer anomaly map is the result of regional and local anomalies superimposing. It is therefore necessary to separate these two components by trend surface, which is a mathematical filtering procedure obtained by fitting a polynomial function using the method of least squares by using the Geosoft Oasis Montaj 7.0.1 software. The regional anomaly map (Fig. 6b) rather represents largescale changes such as crustal thickening or thinning. The residual anomaly map (Fig. 6c) of the Rehamna Massif, which locally expresses the presence of geological bodies without influence of changes in crustal properties, was calculated by the difference between the two anomaly maps (Duque et al., 2007). In this work, we used two digital filters to improve the analysis and structural interpretation of gravimetric and aeromagnetic reduced to pole (RTP) residual data, namely "First vertical derivative" and "Horizontal gradient". These two methods have proven to be effective in mapping geological structures such as magmatic rocks and geological contacts (Cordell, 1979; Fedi \& Florio, 2001; Dubois et al., 2011). 


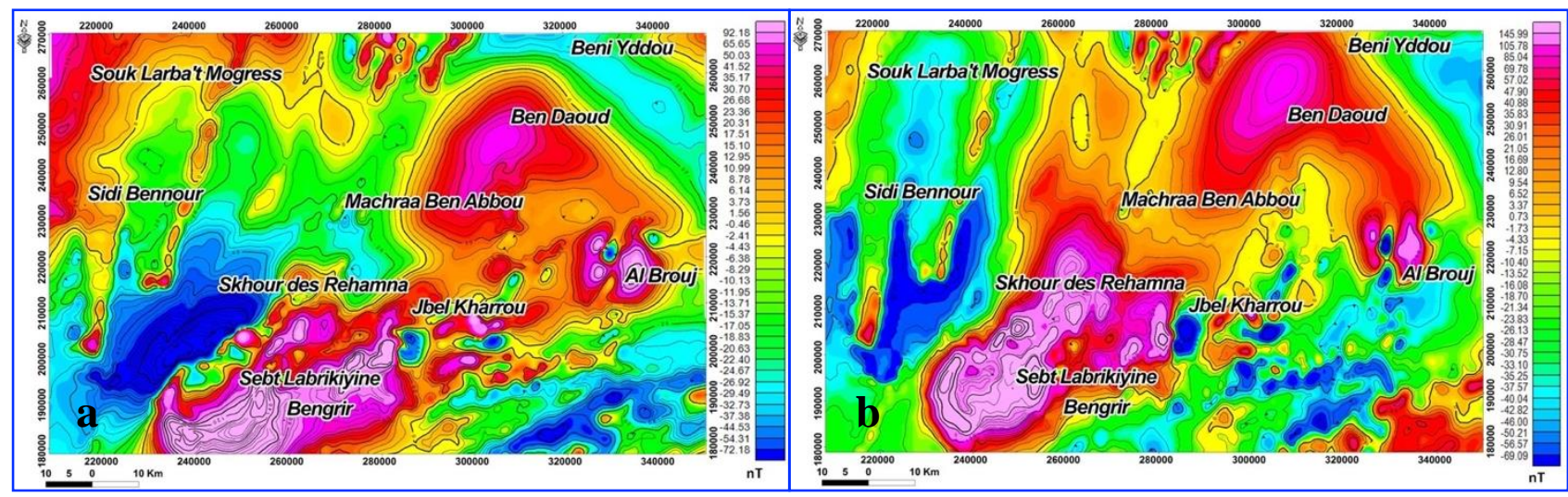

Fig. 5. (a) Residual magnetic field map; (b) Map of reduction to the pole.
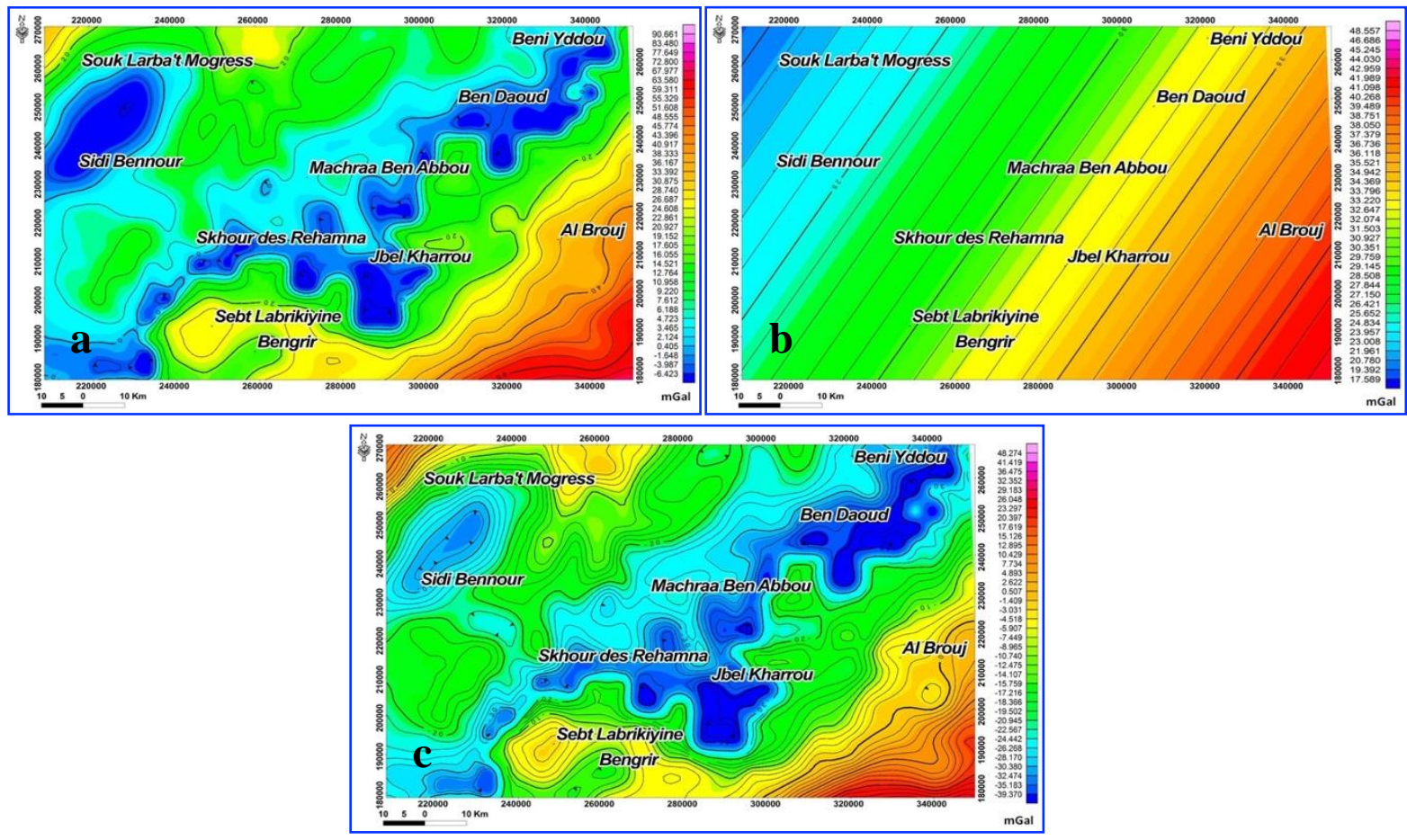

Fig. 6. (a) Bouguer anomaly map; (b) Regional anomaly map; (c) Residual anomaly map.

\subsection{The first Vertical Derivative}

This filter represents the rate at which the magnetic and gravimetric field varies along the vertical. It is often applied to gravimetric and magnetic reduced to pole residual data to refine the edges of existing anomalies on the map (Dubois et al., 2011). The calculation of the first vertical derivative removes the long wavelength components of the magnetic and gravimetric field and allows the accentuation of short wavelength anomalies and the enhancement of the amplitude of sub-surface geological structures. This technique tends to reduce the phenomenon of coalescence of the anomalies. Thus, smaller anomalies are more easily apparent in areas of strong regional perturbations (Dubois et al., 2011). The first vertical derivative is applied to the reduced to pole magnetic field map and to the residual gravity anomaly map. It allows to highlight numerous circular and linear magnetic and gravimetric features such as rock formation boundaries, faults or folds. The algorithm is given by formula (1) for magnetic data and formula (2) for gravimetric data: 


$$
d V=\frac{\partial M}{\partial z}(1)
$$

M: the magnetic field.

$$
d V=\frac{\partial \Delta g}{\partial z}(2)
$$

$\Delta \mathrm{g}$ : gravity measurement.

Analysis by the first vertical derivative allows, in the absence of intra-sedimentary heterogeneities, to recognize the upper and lower parts of the base (Everaerts \& Mansy, 2001; Khattach et al., 2004; Khattach et al., 2006). This transformation should mitigate the regional component that distorts and sometimes masks the relationships between the geology of a shallow basement and the shape of anomalies (Khattach et al., 2004; Khattach et al., 2006).

\subsection{Horizontal Gradient}

The horizontal gradient filter is a simple approach that allows the localization and direction calculation of linear structures such as lithological contacts and faults from potential geophysical data (Cordell and Grauch, 1985). The most important advantage of the horizontal gradient method is its low sensitivity to noise as it requires only calculations of the two first-order horizontal derivatives of the field (Philips, 1998). For the magnetic field, the amplitude of the horizontal gradient is given by formula (3) and formula (4) for gravimetric data (Cordell, 1979):

$$
G H(x, y)=\sqrt{\left(\frac{\partial M}{\partial x}\right)^{2}+\left(\frac{\partial M}{\partial y}\right)^{2}}
$$

M: is the magnetic field.

$$
G H(x, y)=\sqrt{\left(\frac{\partial \Delta g(x, y)}{\partial x}\right)^{2}+\left(\frac{\partial \Delta g(x, y)}{\partial y}\right)^{2}}
$$

where $\Delta \mathrm{g}$ is the gravity anomaly, $\Delta \mathrm{x}$ and $\Delta \mathrm{y}$ are the first-order horizontal derivatives with respect to $\mathrm{x}$ and y directions, respectively. The horizontal derivatives of equation (4) were estimated by the following equations (Blakely, 1995) by using the simple finite difference and discrete value method of $\Delta \mathrm{g}(\mathrm{x}, \mathrm{y})$, if the discrete measurements are carried out at uniform sample intervals:

$$
\begin{aligned}
& \frac{\partial \Delta g(x, y)}{\partial x}=\frac{\Delta g_{i+1 j}-\Delta g_{i-1 f}}{2 \Delta x} \\
& \frac{\partial \Delta g(x, y)}{\partial y}=\frac{\Delta g_{i j+1}-\Delta g_{i j-1}}{2 \Delta y}
\end{aligned}
$$

where $\mathrm{i}$ and $\mathrm{j}$ represent the discrete values of $\Delta g(x, y)$ on the observation plane at uniform sample intervals $\Delta \mathrm{x}$ and $\Delta \mathrm{y}$ Additionally;

$x$ : east coordinate

$y$ : north coordinate 


\section{Results and Discussion}

In general, the qualitative interpretation and multi-scale analysis of contacts is done by visual inspection of maps, as an aid to structural interpretation or mapping, using aeromagnetic and gravimetric data for the detection and location of deep structures, geological contacts, or the edges of magnetic and gravimetric sources.

\subsection{The first Vertical Derivative (FVD)}

The vertical derivative component of magnetic intensity of the region varies from a minimum value of $-0.03 \mathrm{nT} / \mathrm{m}$ to a maximum value of $0.04 \mathrm{nT} / \mathrm{m}$ (Fig. 7). Based on the intensity range, and on the character and shape of the magnetic gradient responses, the FVD map is characterized by low values of positive magnetic gradient over a moderate magnetic background, which characterize the magnetic signature of the surrounding rocks (Fig. 7).The magnetic anomaly map of the vertical gradient in the Ben Daoud zone and around Sebt Labrikiyiine shows a very large circular magnetic gradient of positive intensity (Fig. 7). As shown on the pole reduction map (Fig. 5b), this anomaly could not be due solely to a deep structure, but the limit of this anomaly is accentuated, as the application of derived filters tends to accentuate the edges of the anomaly sources. In addition, the currently improved magnetic data show more isolated and linear magnetic features, which are due to deep sources.

Several linear features have been identified on the map of the first vertical derivative and are interpreted as NNE-SSW to E-W direction faults bounding geological formations and which are of variable length and continuity. Some of these basement anomalies may be due to deep structural features according to their orientation and disposition.

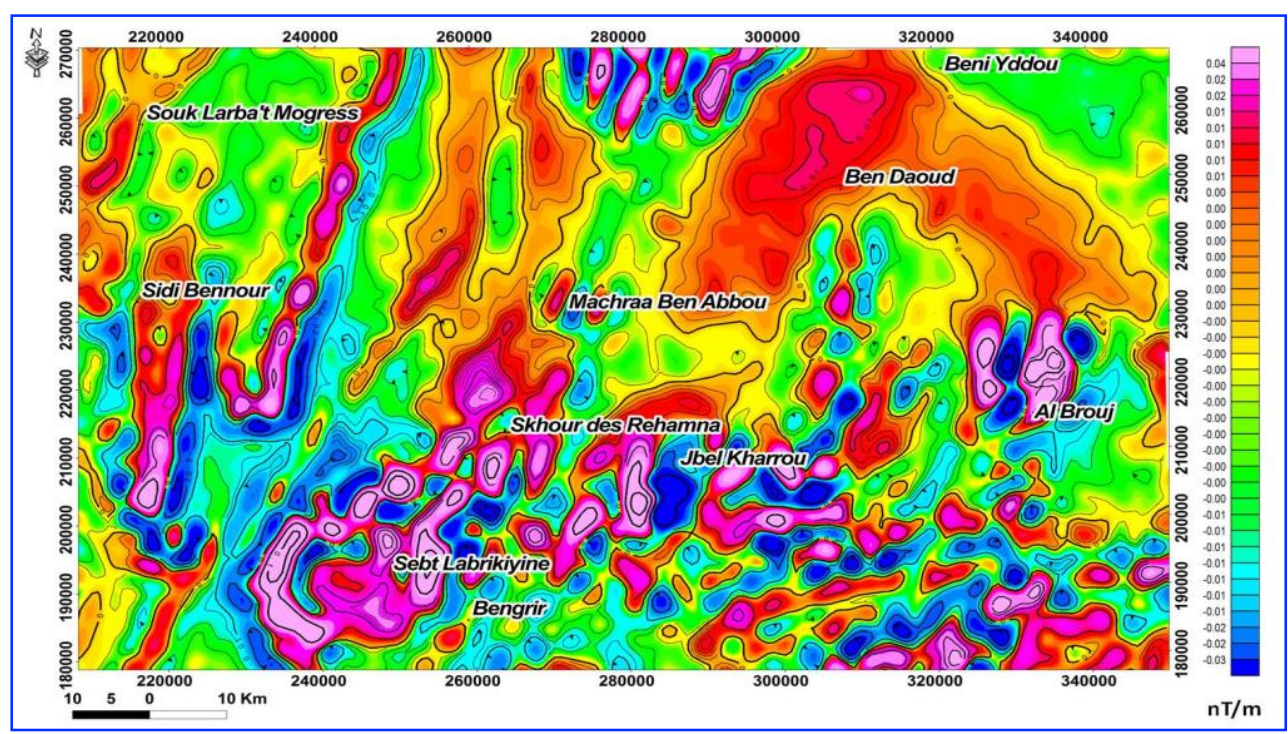

Fig. 7. Vertical derivative of the aeromagnetic anomaly

The map of residual gravity anomalies (Fig. 6c) shows values between -39.4 and $48.3 \mathrm{mGal}$. The map of the first vertical derivative (Fig. 8) of the residual gravity anomaly gives more details on the surface structures which are better circumscribed. It shows a relative maximum oriented NE-SW to NS. Between Sidi Bennour and Souk Larba't Mogress there is a significant enclosure of negative gravity gradient which may produce by the sedimentary cover rocks of lesser density. Another wide and elongated negative anomaly distributed relatively diagonally south of Beni Yaddou, Ben Daoud, Jbel Kharou and Skhour Rehamna. Two large N-S trending positive anomalies in the vicinity of Sebt Labrikiyine coincide with the location of the Hercynian granites and southwest of Jbel Kharrou. These 
two gravimetric anomalies superimpose on the positive anomaly of the reduced magnetic field map at the pole. Another positive anomaly with a very high intensity elongated to the northeast of Jbel Kharrou and to the south of Ben Daoud.

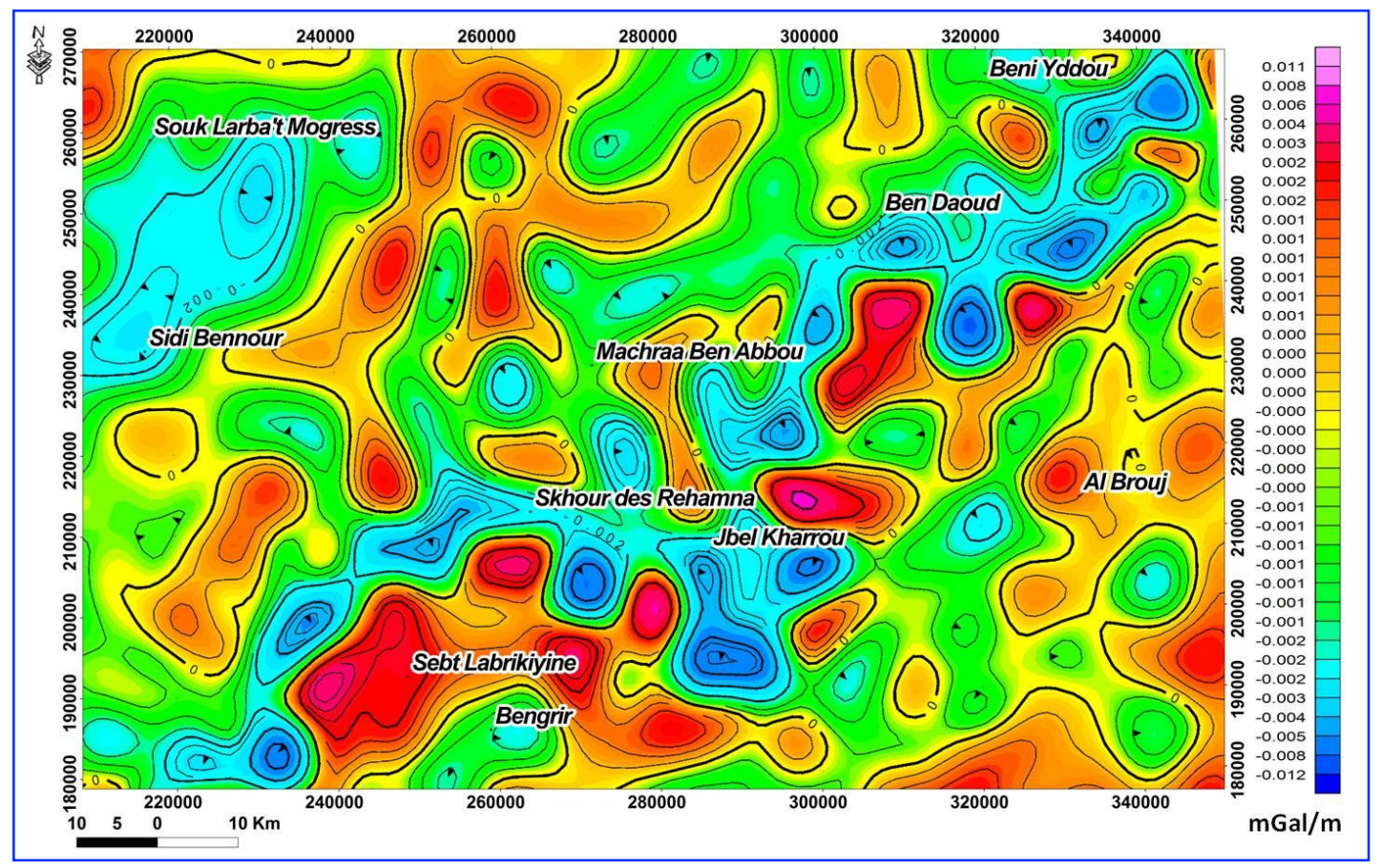

Fig. 8. Vertical derivative of the gravimetric residual anomaly.

The sources of the magnetic and gravimetric anomalies at Skhour Rehamna and Sebt Labrikiyiine correspond to the Precambrian basement mainly composed of granitic formations (Razin et al., 2003). The entire zone is faulted and shows several narrow magnetic features with NNE-SSW and E-W directions. Many lithological and geological features such as the emplacement of the identified magmatic rocks or discontinuities are due to the movement of the Precambrian basement, which was reworked during the Hercynian orogeny.

\subsection{The horizontal Gradient}

The horizontal gradient method provides a continuous, thin and straight contact location (Figs. 9 and 10). The horizontal gradient map is characterized by positive values in a moderate background. It shows circular and elliptical magnetic anomalies, which are clearly visible at El Brouj, Skhour Rehamna and Sebt Labrikiyiine, and major positive linear anomalies in N-S, NNE-SSW, NE-SW and E-W directions (Fig. 9). The gravity anomaly map (Fig. 10) shows that the N-S to E-W direction linear anomalies correspond to a geological contact zone with a large difference in density probably caused by intrusions or outcrops of magmatic bodies. Between Sidi Bennour and Souk Larba't Mogress, the dip signs extracted from the horizontal gradient map show a syncline-oriented NNE-SSW and limited in its eastern part by an anticline. The directional rosette (Figs. 11and 12) highlights much more clearly the directions of the magnetic and gravimetric lineaments shown on the horizontal gradient map, allowing them to be correlated efficiently with the known geological structures and faults (Fig. 13) which can be mineralized (Figs. 14 and 15). 


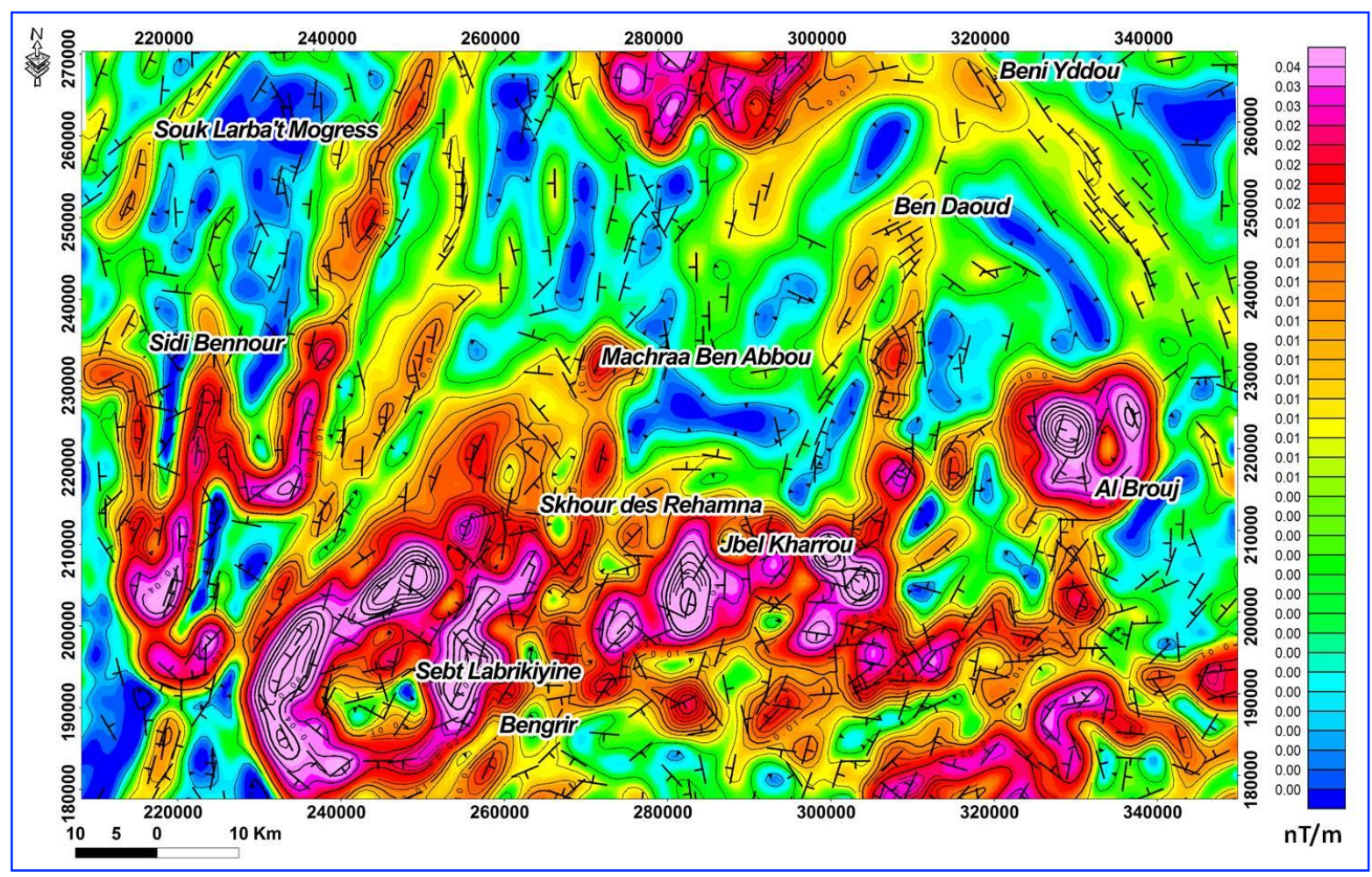

Fig. 9. Horizontal derivatives of the RTP aeromagnetic anomaly.

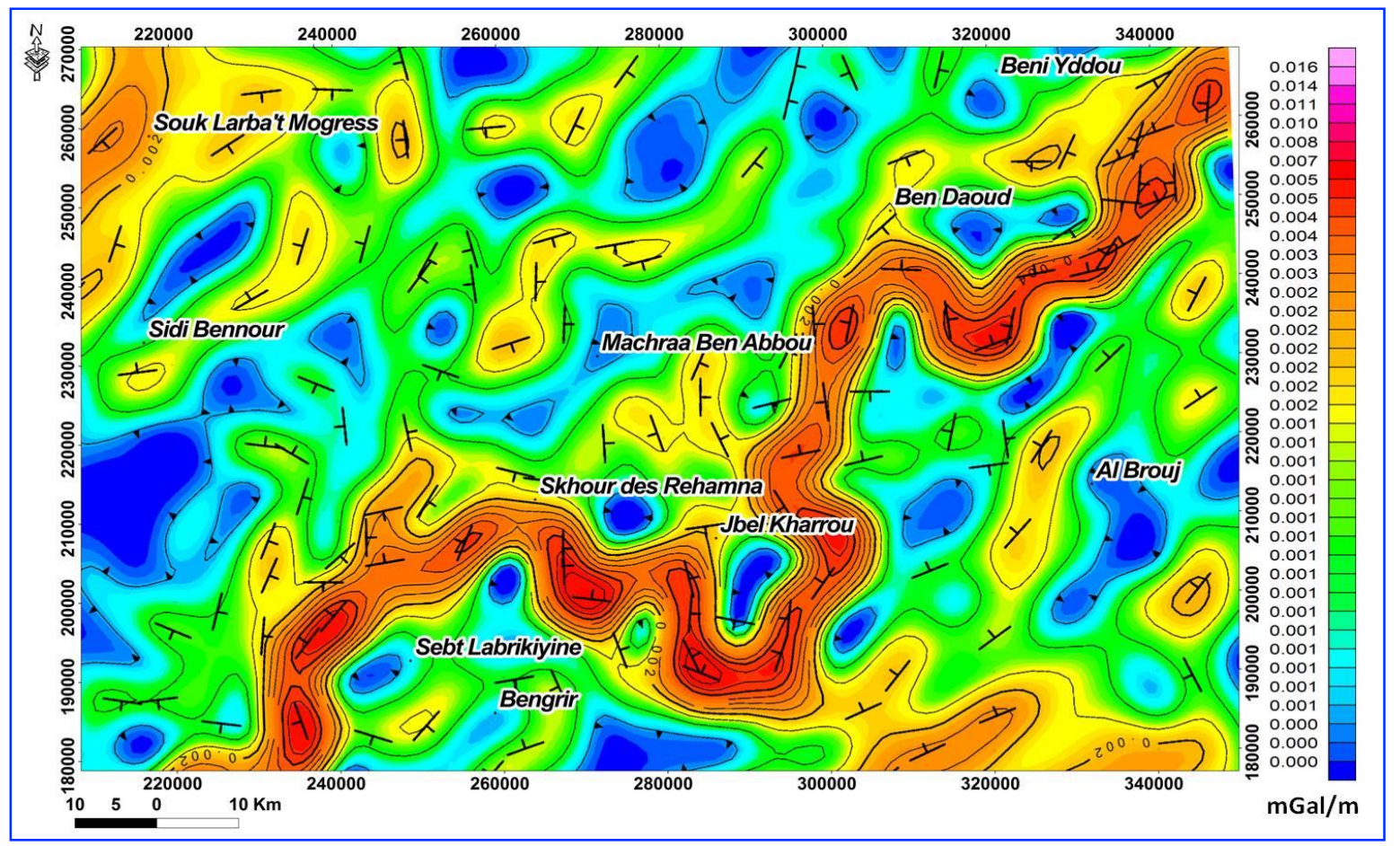

Fig. 10. Horizontal derivatives of the residual gravimetric anomaly. 


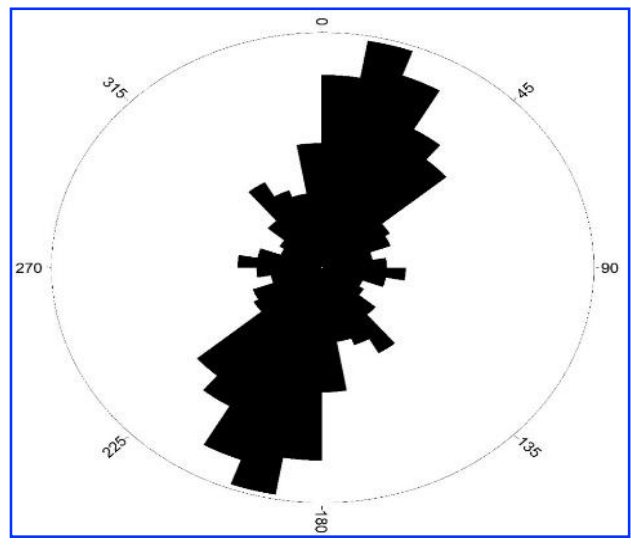

Fig. 11. Directional rosette of aeromagnetic linear features.

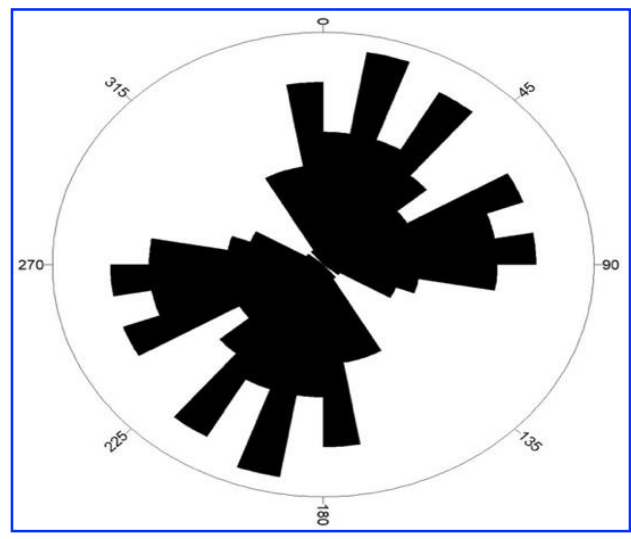

Fig. 12. Directional rosette of gravimetric linear features.

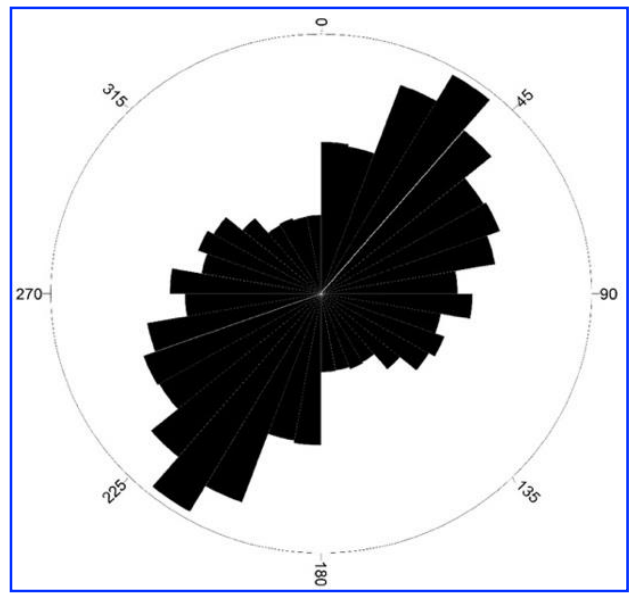

Fig. 13. Directional rosette of geological contacts

\section{Conclusions}

The analysis and interpretation of aeromagnetic and gravimetric data from the Rehamna Hercynian Massif, using first derivative vertical and horizontal gradient filtering techniques, showed the presence of a new contact network at depth and subsurface that is amenable to mineralization. The structural analysis of the first vertical derivative map of the reduced to pole (RTP) magnetic field map shows that 
the main extension direction of the faults and tectonic structures is N-S to NE-SW with the predominance of the NNE-SSW direction. While the residual gravity map shows directions varying between N-S and E-W. These directions are well confirmed by the geological data with a predominance of the NE-SW direction. Thus, the major linear features at depth and subsurface follow the general trend of the major faults that controlled the Hercynian tectonic evolution of the Western Meseta. In addition, the superposition of the mineral showings on the geophysical results obtained, shows that the mineralization of the precious metals mined (Mouttaqi et al., 2011) is located at the level of the Skhour Rehamna, Ras El Abiod and Lalla Tittaf granites.

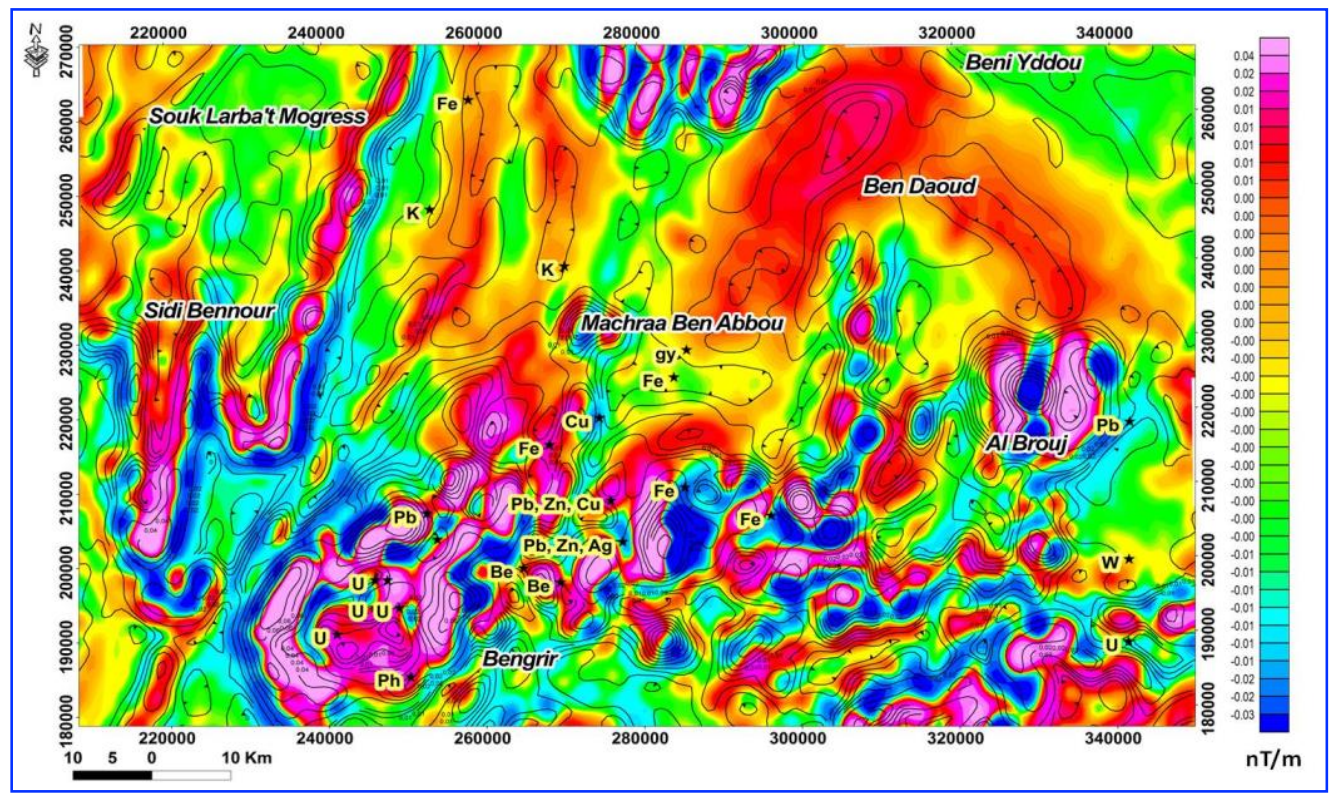

Fig. 14. Superimposing maps aeromagnetic of the vertical derivative, horizontal gradient and mineral indices

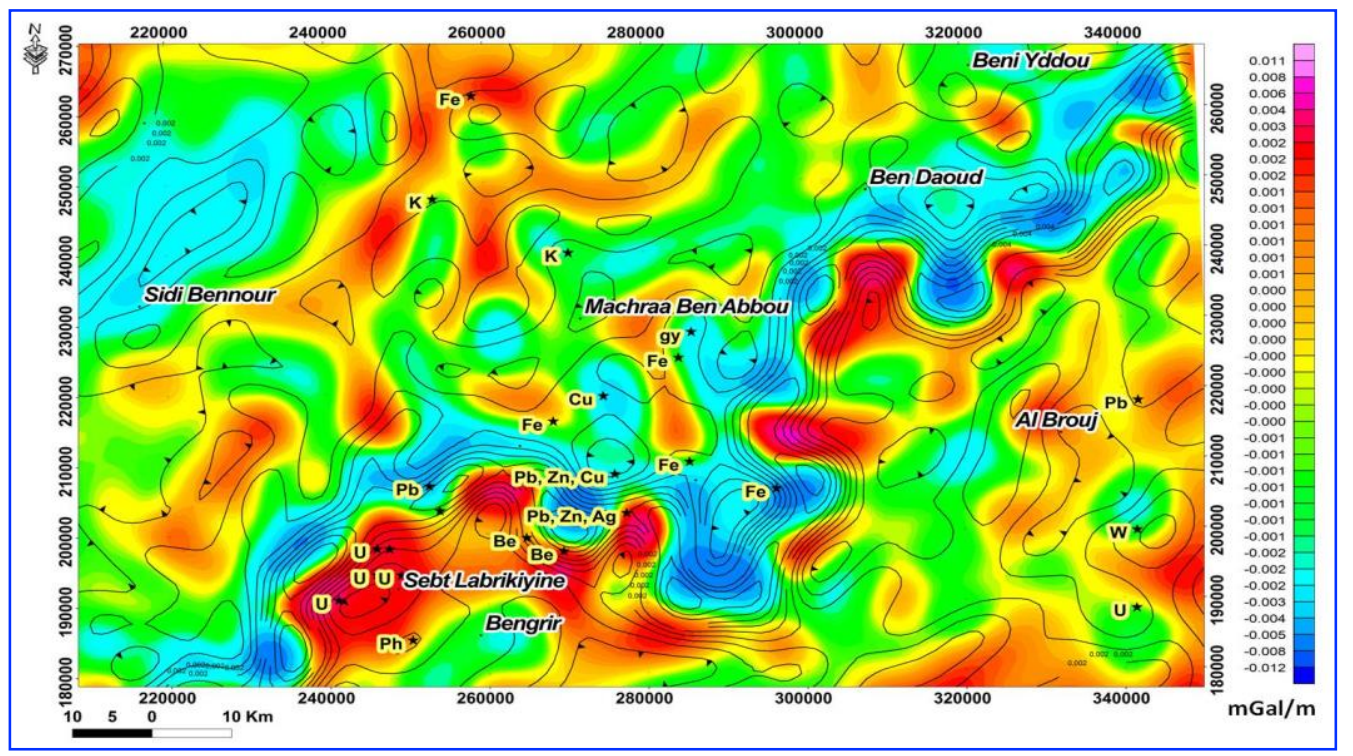

Fig. 15. Superimposing maps gravimetric of the vertical derivative, horizontal gradient and mineral indices 


\section{Acknowledgements}

The authors are very grateful to the Editor in Chief Prof. Dr. Salih M. Awadh, the Secretary of Journal Mr. Samir R. Hijab. and the Technical Editors for their great efforts and valuable comments.

\section{References}

Abderbi, J., \& Khattach, D., 2011. Apport des données aéromagnétiques et gravimétriques à l'étude de la structure géologique des Hauts Plateaux méridionaux (Maroc). Journal of Hydrocarbons Mines and Environmental Research, 2, 111-118.

A.G.C., 1970. Compagnie Africaine de Géophysique, Direction des Mines et de la Géologie du Maroc, Ministère de l'Energie, des Mines et du Développement Durable.

Aghzer, A. M., 1994. Evolution tectonothermale du massif hercynien des Rehamna (Zone centre-mesetienne, Maroc). These doctorale. Universidad complutense de madrid. Facultad de ciencias eológicas. Complutense, Madrid. 358p.

Aghzer, A. M., \& Arenas, R., 1998. Evolution métamorphique des métapélites du Massif hercynien des Rehamna (Maroc) : implications tectonothermales. Journal of African Earth Sciences, 27(1), 20.

Amar, M., Manar, A., \& Boualoul, M., 2012. Apport de la cartographie aéromagnétique à l'identification structurale du système aquifère des sources de l'oasis de Figuig (Maroc). Bulletin de l'Institut Scientifique Rabat, Section Sciences de La Terre, 34, 29-40.

Amar, N., Khattach, D., Azdimousa, A., Chourak, M., Jabaloy, A., Manar, A., \& Amar, M., 2015. Structure and peridotite of Gibraltar arc southern bloc: gravimetric and aeromagnetic evidences. Arabian Journal of Geosciences, 8(11), 9801-9813.

Baudin, T., Chevremont, P., Razin, P., Youbi, N., Andries, D., Hoepffner, C., 2003. Carte géologique du Maroc au 1/50 000 Feuille de Skhour des Rehamna. Ministère de l'Energie et Mines. Direction de la Géologie. Edition du service géologique du Maroc. Notes et Mémoires $\mathrm{N}^{\circ} 435$.

Belkabir, A., Gibson, H. L., Marcoux, E., Lentz, D., \& Rziki, S., 2008. Geology and wall rock alteration at the Hercynian Draa Sfar Zn-Pb-Cu massive sulphide deposit, Morocco. Ore Geology Reviews, 33(3-4), 280306.

Benchekroun, f, \& Essarraj, S., 2015. Modélisation Thermodynamique de la Composition du Fluide Argentifère du gisement d'argent de Roc Blanc, Jebilet, Maroc. Notes et Mémoires du Service Géologique. № 579.

Benhamou, E. H., \& Moumou, Y., 2015. Caractérisation minéralogique et structurale des minéralisations filoniennes à métaux de base des Jbilets centrales - Maroc : Étude de quelques secteurs filoniens au Nord de Marrakech. Rapport de fin d'études. Université Cadi Ayyad. Faculté des sciences et techniques Marrakech - Département des Sciences de la Terre. Laboratoire Géo-Ressources.

Blakely, R.J., 1995. Potential Theory in Gravity and Magnetic Applications. Cambridge: Cambridge University press. XIX + 441 p., ISBN 0-521-41508-X.

Boummane, M. H., \& Olivier, P., 2007. The Oulad Ouaslam Variscan granitic pluton (Jebilets Massif, Southwestern Moroccan Meseta): A forcibly emplaced laccolithic intrusion characterized by its magnetic and magmatic fabrics. Journal of African Earth Sciences, 47(1), 49-61.

Boutirame, I., Boukdir, A., Akhssas, A., \& Manar, A., 2019. Geological structures mapping using aeromagnetic prospecting and remote sensing data in the karstic massif of Beni Mellal Atlas, Morocco. Bulletin of the Mineral Research and Exploration, 213-229.

Bouya, N., Ouardi, H. E., Habibou, E. H., Mercier, E., \& Ansan, V., 2013. Interprétation géologique des données aéromagnétiques et leur utilisation pour la cartographie des structures du plateau d'Agourai (Moyen Atlas tabulaire, Maroc). Africa Geoscience, 20(1-2), 13-20.

Chopin, F., Corsini, M., Schulmann, K., El Houicha, M., Ghienne, J.-F., \& Edel, J.-B., 2014. Tectonic evolution of the Rehamna metamorphic dome (Morocco) in the context of the Alleghanian-Variscan orogeny. American Geophysical Union. Tectonics, 33(6), 1154-1177.

Cordell, L., 1979. Gravimetric expression of graben faulting in Santa Fe country and the Espanola Basin, New Mexico. In New Mexico Geological Society. 30th Annual Fall Field Conference Guidebook, 59-64. 
Cordell, L., \& Grauch, V. J. S., 1985. Mapping basement magnetization zones from aeromagnetic data in the San Juan Basin, New Mexico, in Hinze, W. J., Ed., The utility of regional gravity and magnetic anomaly maps: Society Exploration Geophysics, 181-197.

Cornée, J.J., 1982. Etude lithostratigraphique et tectono-métamorphique des Rehmana sud-orientales plissements et nappes contribution a la connaissance de la chaîne hercynienne en meseta marocaine. Thèse de Doctorat. Univérsité de droit, d'économie et des sciences d'Aix-Marseille, Faculté des Sciences et Techniques de St.Jérôme.Ser. B (20), 175.

Corsini, M., Muller, J., Cornée, J.-J., \& Diot, H., 1988. Découverte de la série basale du Cambrien et de son substratum dans les Rehamna centraux, hautfond au Cambrien (Méséta marocaine). Prémices de l'orogenèse hercynienne. Comptes Rendus de l'académie Des Sciences Paris, 306, 63-68.

Diot, H., 1989. Mise en place des granitoides hercyniens de la meseta marocaine. Thèse de Doctorat. Université Paul Sabatier. Faculté des Sciences de la Terre. Toulouse.

Dubois, J., Diament, M., Cogné, J.-P., \& Mocquet, A., 2011. Géophysique. Cours et exercices corrigés (5e édition). Dunod. France. 275pp.

Duque, J.C., Ramos, R., \& Suriñach, J., 2007. Supervised regionalization methods: A Survey. Research Institute of Applied Economics. International Regional Science Review, 30,195-220.

El Arbaoui, W., Essaifi, S., Radnaoui, \& Maacha, L., 2015. Le gisement de Jbel Haïmer à Cu-Au (Jebilet centrales, Maroc). Ministère de l'Energie et Mines. direction de la Géologie. Edition du service géologique du Maroc. Notes et mémoires, 579.

El Gout, R., Khattach, D., \& Houari, M. R., 2009. Etude gravimétrique du flanc nord des Béni Snassen (Maroc nordoriental): implications structurales et hydrogéologiques. Bulletin de l'Institut Scientifique, Rabat, section Sciences de la Terre, $\mathrm{n}^{\circ} 31,61-75$.

El Gout, R., Khattach, D., Houari, M. R., Kaufmann, O., \& Aqil, H., 2010. Main structural lineaments of northeastern Morocco derived from gravity and aeromagnetic data. Journal of African Earth Sciences, 255-271.

El Hadi, H., Tahiri, A., Simancas Cabrera, F., González Lodeiro, F., Azor Pérez, A., \& Jesús Martínez Poyatos, D., 2006. Un exemple de volcanisme calco-alcalin de type orogénique mis en place en contexte de rifting (Cambrien de l'oued Rhebar, Meseta occidentale, Maroc). Comptes Rendus Geoscience, 338(4), 229-236.

El Mahi, B., 1991. Evolution tectono-metamorphique hercynienne des Rehamna centraux. Exemple d'interaction entre metamorphisme et mise en place de leucogranites dans une zone de cisaillement intralithospherique : la zone de cisaillement de la meseta occidentale (z.c.m.o.). Thèse de Doctorat. Université Mohammed V. Faculté des Sciences de Rabat. Maroc. 237pp.

El Mahi, B., Hoepffner, C., Zahraoui, M., \& Boushaba, A., 1999. L’évolution tectono-métamorphique de la zone hercynienne des Rehaman centraux (Maroc). Bulletin de l'Institut Scientifique, Rabat, (22), 41-57.

El Mahi, B., Zahraoui, M., Hoepffner, C., Boushaba, A., Meunier, A., \& Beaufort, D., 2000. Les veines synmétamorphiques de quartz à disthène : témoins d'un métamorphisme associé à l'amincissement postorogénique (Meseta occidentale, Maroc) Kyanite-quartz synmetamorphic veins : Indicators of postorogenic thinning and metamorphism (Western Meseta, Morocco). Pangea, 33-34, 23.

El Kamel, F., 1987. Géologie du paléozoïque des Rehamna nord-orientaux, Maroc. Évolution sédimentaire et structuration hercynienne d'un bassin dévono-carbonifère. Sédimentation et déformation des molasses post-orogénique. Thèse de Doctorat. Université Aix-Marseille III.

El Kamel, F., \& El Hassani, A., 2006. Étapes de la structuration et de la sédimentation du bassin viséen de Mechra ben Abbou (Meseta occidentale marocaine). Geodiversitas, 28(4), 14.

El Kamel, F., Remmal, T., \& Mohsine, A., 1998). Mise en évidence d'un magmatisme alcalin d'intraplaque postCalédonien dans le bassin silurien des Ouled Abbou (Meseta côtière, Maroc), C. R. Acad. Sci. Paris. Sciences de la terre et des planétes. 327, 309 - 314.

Essaifi, A., Potrel, A., Capdevila, R., \& Lagarde, J.-L. 2003. Datation U-Pb : âge de mise en place du magmatisme bimodal des Jebilet centrales (chaîne Varisque, Maroc). Implications géodynamiques. Comptes Rendus Geoscience, 335(2), 193-203.

Everaerts, M., \& Mansy, J. L., 2001. Le filtrage des anomalies gravimétriques : une clé pour la compréhension des structures tectoniques du Boulonnais et de l'Artois (France). Bulletin Society Géology France, 172(3), 267274. 
Fedi, M., \& Florio, G., 2001. Detection of potential fields source boundaries by enhanced horizontal derivative method. Journal of Geophysical Prospecting, (49), 40-58.

Gasquet, D., Stussi, J.-M., \& Nachit, H., 1996. Les granitoïdes hercyniens du Maroc dans le cadre de l'évolution géodynamique régionale. Bulletin Society géology France, 167(4), 517-528.

Gigout, M., 1951. Etudes géologiques sur la Méséta marocaine occidentale (arrière-pays de Casablanca, Mazagan et Safi). Notes et Mém. Serv. géol. Maroc., 86, 507 pp.

Haïmeur, J., \& Hassani, I.-E. E. A. E., 2005. Rôle du brassage et du stockage magmatique dans l'homogénéisation des granitoïdes calco-alcalins: Cas du pluton composite de Zaër (Maroc central). Eclogae Geologicae Helvetiae, 98(2), 219-236.

Hoepffner, C., Jeannette, D., Jenny, P., Michard, A., \& Pique, A., 1975. Relations entre une tectonique de decrochement et un metamorphisme a disthene dans le massif hercynien des Rehamna (Maroc). Bulletin de La Societe Geologique de France, S7-XVII (3), 421-429.

Hoepffner, C., 1974. Contribution à la géologie structurale des Rehamna (Meseta marocaine méridionale), Le matériel paléozoïque et son évolution hercynienne dans l'est du massif. Thèse de Doctorat. Université Louis Pasteur de Strasbourg,153pp.

Hoepffner, C., Soulaimani, A., \& Piqué, A., 2005a. The Moroccan Hercynides. Journal of African Earth Sciences, 43(1-3), 144-165.

Hoepffner, C., Soulaimani, A., \& Piqué, A., 2005b. The Moroccan Hercynides. Journal of African Earth Sciences, 43(1-3), 144-165.

Hoepffner, C., Houari, M. R., \& Bouabdelli, M., 2006. Tectonics of the North African Variscides (Morocco, western Algeria): an outline. Comptes Rendus Geoscience, 338(1-2), 25-40.

Hoepffner, C., Ouanaimi, H., \& Michard, A., 2017. La Meseta, un terrain vagabond ou la marge fragmentée de l'Anti-Atlas ?. Géologie Fondamentale: Etat des connaissances et Résultats Récents. Notes et Mém. 149, 5 .

Jarni, A., Jaffal, M., Mouguina, E. M., Maacha, L., En-aciri, O., Outhounjite, M., Ouadjou, A. , Zouhair, M., Radnaoui, A. and Saddiqi, O., 2015. Les anomalies magnétiques de la province métallogénique des Jebilets - Guemassa (Maroc hercynien) : Etat des connaissances et problématique liée à l'exploration minière. International Journal of Innovation and Applied Studies, 12 (2), 491-504.

Khattach, D., Keating, P., Mili, E. M., Chennouf, T., Andrieux, P., \& Milhi, A., 2004. Apport de la gravimétrie à l'étude de la structure du bassin des Triffa (Maroc nord-oriental): implications hydrogéologiques. Comptes Rendus Geoscience, (336), 1427-1432.

Khattach, D., Mraoui, H., Sbibih, D., \& Chennouf, T., 2006. Analyse multi-échelle par ondelettes des contacts géologiques : application à la carte gravimétrique du Maroc nord-oriental. Comptes Rendus Geoscience, 338, 521-526.

Michard, A., 1982. Le massif paléozoïque des Rehamna (Maroc) : stratigraphie, tectonique et pétrogenèse d'un segment de la chaîne varisque. Notes et mém, 303, 180 .

Michard, A., Soulaimani, A., Hoepffner, C., Ouanaimi, H., Baidder, L., Rjimati, E. C., \& Saddiqi, O., 2010. The South-Western Branch of the Variscan Belt: Evidence from Morocco. Tectonophysics, 492(1-4), 1-24.

Michard, A., Saddiqi, O., Chalouan, A., \& De Lamotte, F., 2008. Continental evolution: the geology of Morocco: structure, stratigraphy, and tectonics of the Africa-Atlantic-Mediterranean triple junction. Berlin : Springer, 65-121.

Mouttaqi, A., Rjimati, E. C., Maacha, L., Michard, A., Soulaimani, A., \& Ibouh, H., 2011. Nouveaux guides géologiques et minièrs du Maroc. Les principales mines du Maroc. Notes et mémoires service géologique du Maroc, 9, 375.

Nait Bba, A., Boujamaoui, M., Amiri, A., Hejja, Y., Rezouki, I., Baidder, L., Inoubli, M.H., Manar, A., Jabour, H., 2019. Structural modeling of the hidden parts of a Paleozoic belt: Insights from gravity and aeromagnetic data (Tadla Basin and Phosphates Plateau, Morocco). Journal of African Earth Sciences, 151, 506-522.

Nerci, Kh., 2006. Les minéralisations aurifères du district polymétallique de Tighza (Maroc central) : un exemple de mise en place périgranitique tardi-hercynienne. Thèse de Doctorat. Université d'Orléans, France. 
Nshimiyimana, F., Essarraj, S., Hibti, M., Boulvais, Ph., Boyce, A., Marignac, C., \& Maacha. L., 2018. The Koudia El Hamra Ag- $\mathrm{Pb}-\mathrm{Zn}$ deposit, Jebilet, Morocco: Mineralogy and ore fluid characterization. Journal of African Earth Sciences, 145, 1-17.

Pereira, M. F., El Houicha, M., Chichorro, M., Armstrong, R., Jouhari, A., El Attari, A., 2015. Evidence of a Paleoproterozoic basement in the Moroccan Variscan Belt (Rehamna Massif, Western Meseta). Precambrian Research, 268, 61-73.

Philips, J. D., 1998. Processing and interpretation of aeromagnetic data for the Santa Cruz Basin-Patagonia mountains area. South-Central Arizona. U. S. Geological Survey Open-File Report. Arizona., 02-98.

Piqué, A., 1972. Contribution à la géologie structurale des Rehamna (Meseta marocaine méridionale). Le matériel paléozoïque et son évolution hercynienne dans l'ouest du massif. Thèse de Doctorat. Université Louis Pasteur de Strasbourg, 148 .

Rais-Assa, R., 1984. Etude géologique de la partie occidentale du massif hercynien des Rehamna septentrionales (Meseta marocaine). Lithostratigraphie, plissements et métamorphisme, chevauchements et nappes. Thèse de Doctorat. Université de droit, d'économie et des sciences d'Aix-Marseille, Faculté des Sciences et Techniques de St. Jérôme.

Razin, P., Baudin, T., Chevremont, P., Andries, D., Youbi, N., Hoepffner, C., 2003. Carte géologique du maroc au 1/50 000 feuille de jebel kharrou. Ministère de l'Energie et Mines. direction de la Géologie. Edition du service géologique du Maroc. Notes et Mémoires N³65.

Tahiri, A., Simancas, J. F., Azor, A., Galindo-Zaldívar, J., González Lodeiro, F., El Hadi, H., 2007. Emplacement of ellipsoid-shaped (diapiric?) granite: Structural and gravimetric analysis of the Oulmès granite (Variscan Meseta, Morocco). Journal of African Earth Sciences, 48(5), 301-313.

Wernert, P., Schulmann, K., Chopin, F., Štípská, P., Bosch, D., \& El Houicha, M., 2016. Tectonometamorphic evolution of an intracontinental orogeny inferred from P-T-t-d paths of the metapelites from the Rehamna massif (Morocco). Journal of Metamorphic Geology, 34(9), 917-940.

Yahyaoui, L., \& Essaifi, A., 2011. Massif des Jbilet (meseta sud-occidentale). In Nouveaux guides géologiques et miniers du Maroc. Notes et mémoire du service géologique du Maroc. 71-82. 